\title{
Psalms 90-106: Book Four and the Covenant with David
}

\section{Introduction}

Most of us are used to studying and praying the psalms as single units of teaching, reflection, praise or prayer. However, when we focus on one entire book within the Psalter, we encounter some very different issues. ${ }^{1}$ It is commonly accepted that the division of the Psalter into five books by way of its five doxologies is in imitation of the Mosaic Torah, thus creating an alternative 'Torah of David'. Hence just as the Torah of Moses in its five books comprises a story whose focus is Moses, using both narrative and law, it could be argued that the Psalter as the 'Torah of David' comprises a different story, through poetry and prayer, whose focus is David - a story about the making, dissolution and renewal of the covenant with David.

The model of 'story', told in five parts, is on the whole appropriate because of the supposed correspondences between the Torah of Moses and the Torah of David. But it is by no means a perfect model, because the medium is not prose narrative, such as we find in Samuel and Kings, or in the books of Chronicles, but poetry - and separate units of poetry at that. I have considered using one of three other models instead, but each has even more limitations. The first is a musical analogy - of a symphony, whereby we might hear the development of a theme in five different movements with different episodes contributing to the differences between each movement : although the western classical symphonic form usually comprises four movements, one might perhaps view the five movements corresponding to, for example, traditional forms such as sonata, scherzo, adagio, allegro and rondo, each contributing harmoniously to an overall 'concert of sound'. Although this is partly appropriate for a book which has more musical associations than any other book in the Hebrew Bible, and a good deal of the poetry is to be heard as much as it is to be read, it would of course be a modern paradigm imposed on an ancient text. Another model I have considered is from the world of art: here the fivefold development of a theme leads us to think of a pentaptych, with its five panels each illustrating five themes in different ways which nevertheless give us an artistic sense of the whole. Again, although this is appropriate because a good deal of what we read we also 'see' with the inner eyes of our imagination, it is the imposition of another relatively recent form on an ancient text. The third model, which I find the most appropriate of the

\footnotetext{
${ }^{1}$ This paper was originally given in August 2014 at a Jewish-Christian colloquium near Osnabrück, now in its $46^{\text {th }}$ year, organized primarily by Rabbi Jonathan Magonet. The study chosen for this particular year was Book Four of the Psalter. My own brief, developed in this paper, was to offer something of the Christian reception of this collection, also giving attention to its Jewish roots.
} 
three, is of a dramatic production in five acts, with different scenes in each act representing the smaller collections within each individual book: this is particularly fitting given the performative nature of psalmody within liturgy, but like the musical and aesthetic models it is helpful only to a point. Each paradigm informs us in part about the Psalter as a whole, and indeed its reception history testifies to its musical, artistic and dramatic potential, but to take any one model too far is to strain the ancient poetry beyond its limits. Hence I am left with the one other analogy, that of story - itself also limited, but one which perhaps best fits with what I intend to argue shortly. So the Psalter might indeed be read as a story - a subtle and intricate account in five books, each book comprising different smaller sub-sections, creating an overall narrative whose themes are thus developed through many different poetic forms. ${ }^{2}$

The focus of attention in this paper is Book Four, Psalms 90-106. I shall argue that this compilation of seventeen psalms might be seen as the fourth component of the story of the Psalter as a whole, with four smaller internal collections comprising four different sub-themes within it. I shall also argue that this story is not one which is explicitly narrated, as one might argue for the Mosaic Torah, but instead it is more implicitly understood as the poetry is performed through prayer and praise and instruction, probably within the liturgy of the Second Temple. So first we encounter three psalms giving rise to more quiet and reflective prayer (Psalms 90-92); we then find the story expressed through loud and jubilant praise (Psalms 93-100); this progresses to more poignant declaration of faith for and by the community as a whole (Psalms 101-103) and finishes with congregational praise and solemn instruction (Psalms 104-106). As for the theme of this story, the overall concern of Book Four as whole seems to be to provide an alternative worldview to that of the covenant with David - not surprising, given the dissolution of the monarchy which is expressed so vividly in Psalm 89 at the end of Book Three. So Book Four is the most radical of all the five books in the 'Torah of David' as it seeks to develop a sense of community identity which is actually informed less by the covenant with David and more by the Exodus traditions and the covenant with Moses.

However, in order to understand the purpose of Book Four in this unfolding story, we need to view, briefly, how this is developed in the Psalter as a whole.

2 See Wallace (2007): 88-94. 


\section{The Story of the Psalter in Five Books}

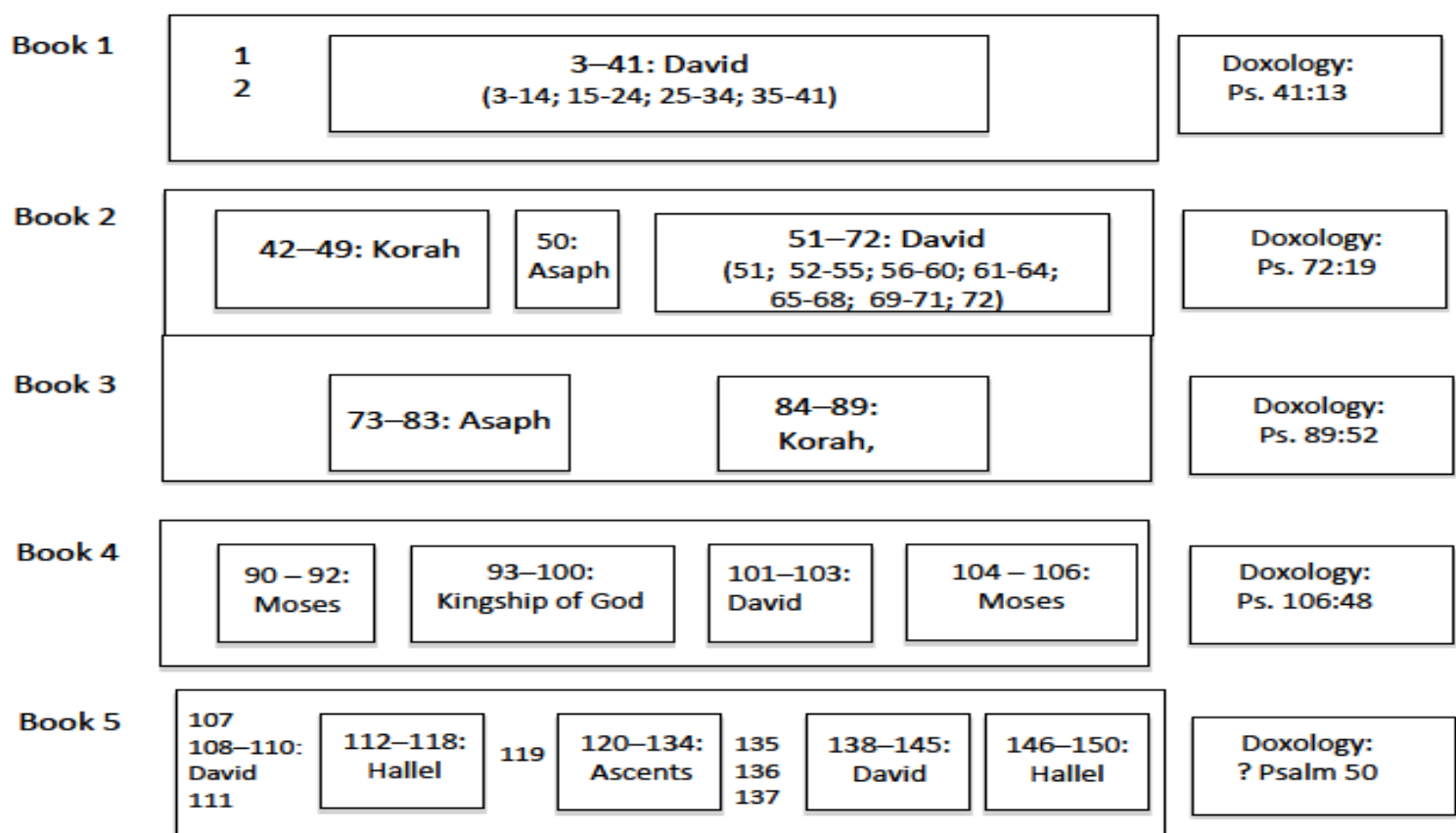

Each of the five books is marked out by a similar doxology added on to the last psalm in the book. However, not only are the books of different lengths, but the interest in the figure of David, determined by the headings over the psalms, differs greatly within each of them. In Book One the heading 'to/for David' (לדוד) occurs over all but two psalms. In Books Two and Three, taken together because of they share both Asaphite and Korahite psalms, the Davidic heading is over twenty-two of the forty-seven psalms. In Book Four, by contrast, this superscription occurs over only two psalms. In Book Five it is found only ten times in the Hebrew text. ${ }^{3}$ So in Book One the figure of David is central, and in Books Two and Three it is also fairly prominent; but in Book Four he almost completely disappears, to reappear in a somewhat minor role in Book Five. Hence even this brief overview reveals something about the rise and fall (and perhaps final renewal) of the covenant with David.

\footnotetext{
${ }^{3}$ This observation applies only to the Hebrew text. The Greek translation of Book Four has a more Davidic emphasis (for example, additional Davidic headings are given to Palms 91, 93-99 and 104). Furthermore, one of the Dead Sea Psalms Scrolls of Book Four (11QPs ${ }^{a}$ ) displays a very different order, whereby Psalms 109 and 118 and 147 are all placed directly after Psalm 103. But this paper is about the story as is told in the Hebrew Bible, not least as it presents itself in the Masoretic Text.
} 
Book One is introduced confidently with the untitled Psalm 2 which announces the establishment of a new Davidic king. Many of the psalms which follow are profoundly personal psalms; they can be grouped thematically into four smaller collections of twelve psalms (3-14) ten psalms (15-24), and another ten psalms ( 25-34), with each collection containing a psalm praising God as Creator at the heart of it. Book One ends with a smaller collection of seven psalms (35-41) on the theme of the 'poor and needy'. Despite the diversity within this first book, the Davidic headings require us to read each psalm as if 'through David'. Here David is viewed as a model of obedient piety, especially in times of suffering.

Book Two, by contrast, begins with part of a Korahite collection (Psalms 42-49) which focuses on Jerusalem and the Temple and the sufferings of the people; there is no reference at all to David. This is also the case with the one isolated Asaphite psalm, 50. This is followed by a second large collection of Davidic psalms (Psalms 51-72) comprising five groups of three, four or five psalms. ${ }^{4}$ The psalms at the beginning and end of this collection (51 and 72) each have headings with somewhat negative Solomonic associations, reminding us of the later problems of the monarchy and the division of the kingdoms. In this collection David himself is portrayed as the national hero who suffers with and on behalf of his people, with the headings often expanded to remind us of stories about David from 1 and 2 Samuel. $^{5}$

Book Three - which is closely connected with Book Two, not only by the dominant name for God as 'Elohim' throughout most of these collections, but also by the Asaphite and Korahite psalms, each comprising a collection of twelve overall - focuses on the problems and the eventual decline of the nation and the end of the Davidic covenant; Psalm 89 ends Book Three by speaking of David's throne being 'hurled to the ground' with God seemingly hidden from his people (89:44-46). ${ }^{6}$

Books Four and Five are very different in content and develop this story in new ways. Book Four comprises three collections of three psalms and one of seven psalms, with an additional psalm (94) breaking up that sequence. Here, as we have already noted, Moses is especially prominent, and

\footnotetext{
${ }^{4}$ Psalms 52-55 each have the title משטיביל alongside David; Psalms 56-60 have the additional heading מכזמרם (Psalm 61, is without this extra heading might be

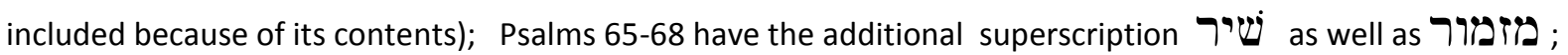
whilst Psalms 69-71, each without further specific titles, form a fifth sub-group on the theme of the innocent sufferer.

${ }^{5}$ For example, Psalms 52; 54; 56; 57; 59; 60.

${ }^{6}$ Versification is from the New Revised Standard Version, unless otherwise stated.
} 
the Exodus traditions are emphasised over and above those of David and Zion, with David appearing only twice in this collection. All these psalms in different ways seek to address the vicissitudes of life by focusing on human fragility over and against the constancy and sovereignty of God: the sense of loss suggests the experience of exile, as I shall argue shortly.

Book Five comprises four large collections. There are also two groups of three psalms, with three points at which a single psalm has been inserted. Book Five is also interested in the Creation and Exodus traditions, and so has many of the features of Book Four. The difference is that Book Five as a whole reflects on better times, celebrating, for example, God's return to Zion through the restored Temple (Psalms 120-134). There is some expression of the hope that the Davidic covenant will be once again part of this celebration: but the theme is muted, particularly when compared with Books One and Two.

Book Four is the focus of this paper. Its seventeen psalms mirror the seventeen in Book Three but whereas Book Three bears witness to the downfall of the king, Psalms 90-106 seem to reflect on what follows chronologically in Israel's history: the consequent experience of the exile. The repeated emphasis on Moses and the Exodus traditions certainly corresponds with other biblical texts which were written during the time of the exile. The best example is Isaiah $40-55$, which also addresses the trauma of the people in Babylon. For example, Book Four begins and ends with pleas to God to 'take pity' on his people (90:13 and 106:45, using נדחם); the beginning and ending of Isaiah 40-55 are on exactly the same theme (Isa. 40:1 and 54:11, also using נפחם) At the beginning of each book, in Ps. 90:5 and Isa. 40:6-8, human frailty is compared with grass (ציר). And in Pss. 96:1 and 98:1, as well as in Isa. 42:10, we read of the 'new song' which is to be sung to celebrate what God will later do for his people. Furthermore, the universal reign of God is defiantly declared throughout both works, for example in Ps. 96:4-5 and Isa. 40:18-23. Each denounces the worship of

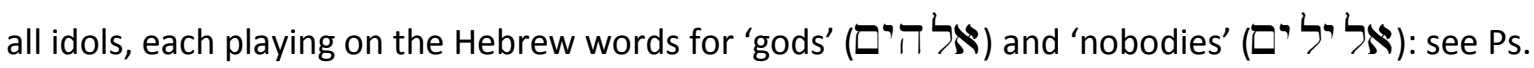
96:5 and Isa. 40:17-18. ${ }^{9}$ There is however one key difference: Book Four is more explicitly interested in Moses - indeed, Moses is only mentioned once in the Psalter outside Book Four, but seven times

\footnotetext{
${ }^{7}$ 'Return O Lord! How long? Have pity on thy servants!' (Ps. 90:3); and 'He caused them to be pitied by all those who held them captive' (Ps.106:45 [Heb 47]).

${ }^{8}$ 'Comfort, comfort [pity, pity] my people, says your God.' (Isa. 40:1). 'O afflicted one, storm-tossed, and not comforted [='not pitied'] ...' (Isa. 54:11).

${ }^{9}$ See Creach (1998): 63-76.
} 
within $i^{10}$ - whilst Isaiah $40-55$ prefers not to refer explicitly to Moses but to the Exodus traditions in general as a basis for hope. Nevertheless, the experience of exile is a significant influence in each case.

So Book Four plays its own part in the story of the beginning, ending and re-making of God's covenant with David. I shall focus not only on the story as part of Israel's history, but also on the story as received particularly in later Christian reception, as this confirms the key themes in Book Four as a whole. ${ }^{11}$ My own approach is very similar to that of Erich Zenger, who, writing on Book Four from a Christian perspective, saw 'Israel und Kirche im gemeinsamen Gottesbund'. ${ }^{12}$ Zenger made it clear that the two faiths are to be interpreted 'side by side', rather than using the psalms to argue for the superiority of one faith over the other. ${ }^{13}$ So the two Jewish covenants of 'Moses and Torah' and 'David and Zion' have to be interpreted alongside the later Christian covenant: this is about Jesus Christ as Teacher and Mediator, like Moses, yet also, born of the line of David, one who inaugurates a new Kingdom, like David. Each faith tradition needs to engage with the other in humility, for as Book Four teaches, each derives its identity not from its own merit but from the mercy (דס) of a God who invites 'all who fear him' (Ps. 103:11, 17) to participate in his Kingdom. ${ }^{14}$

So let us examine further the four parts which make up the story of Book Four. Part One comprises three reflective prayers and directives (Psalms 90-92) with the focus on Moses the Mediator. Part Two, by contrast, is mainly of seven psalms of jubilant praise (Psalms 93, 95-100) where the focus is on the Kingship of God: Psalm 94 interrupts this sequence with a lament on the judgment of God. Part Three contains three psalms of a more subdued nature (Psalms 101-103) and

\footnotetext{
${ }^{10}$ Outside Book Four Moses is referred to only in Ps. 77:21. In Book Four references are found in the title to Psalm 90 and in Pss. 99:6; 103:7; 105:26; 106:16, 23, 32.

${ }^{11}$ The Bibel Forum focussed especially on later Jewish and Christian interpretations of these psalms, primarily through the commentary tradition, but also especially through music and art.

${ }^{12}$ See Zenger (1991): 238-57.

${ }^{13}$ 'Israel und Kirche stehen von Gott her in einem spannungsreichen Verhältnis, das beide wahr- und annehmen müssen, damit sie - in messianscher Weggemeinsschaft - ihrer gemeinsamen Aufgabe gerecht werden können, nämlich "Gottes Reich bei uns einzulassen", oder wenigstens ihm den Weg zu bahnen", beide in ihrer spezifischen Sendung!': Zenger (1991): 236.

${ }^{14}$ 'Israel und Kirche zugleich als "Volk Gottes" zu bezeichnen, müsste entweder den Begriff entleeren ... oder würde die Israel und die Kirche spezifisch zukommende Berufung nivellieren... Wenn Israel sich diese Mitte des Bundes durch die Tora und durch die sich um die Tora als "Zäune" herumlegenden "Propheten" und "Schriften" von der rabbinischen Tradition auslegen lässt, und wenn sich die Christen diese Bundesmitte von Jesus Christus auslegen lassen, werden beide - auf je verschiedene Weise - Zeugen und Eiferer jenes Gottesbundes, der ihnen geschenkt ist - damit SEIN Reich komme': Zenger (1991): 254.
} 
here, briefly, the focus returns to lessons to be learnt by the community from a king like David. Part Four comprises three psalms, beginning with a hymn of creation and ending with serious instructions for the people (Psalms 104-106), where Creation and Exodus, and indeed other stories of Moses, come back in view.

There is much here which allows for both Jewish and Christian readings, not only in shared theology but also in shared experience. The whole of Book Four echoes the concerns of a disenfranchised people, beleaguered in a foreign land, but it also affirms, despite all appearances, that God is still on their side. So as we work through the performance of this story we shall discover this is not just about events in the sixth century BCE, but concerns circumstances which have been experienced continuously by Jewish and Christian communities through the ages: it is as if all who sometimes feel like strangers and sojourners in their own cultural context, yet long for the hidden presence of God, can participate in this story as well.

\section{Part One: Seeking Refuge in God whilst in Exile}

\section{Psalms 90-92: A Moses Collection}

Psalms 90-92 share the common theme of the ephemeral nature of humanity with Moses playing a central part in 'communicating' this. ${ }^{15}$ 'Moses, man of God' is not only in the heading to Psalm 90: parts of Moses' speeches in Deuteronomy 32 and 33 and Exodus 32 are interspersed throughout these three psalms as Moses represents the authoritative mediating voice from the past. ${ }^{16}$ The three psalms move in an increasingly hopeful sequence from lament (Psalm 90) to divine promise (Psalm 91) to thanksgiving (Psalm 92). The key theme in all these three psalms is that, rather than depending on any human institution, God is now the refuge of his people (Pss. 90:1; 91:1-2, 9-10; 92:12-13): he is to be found by 'night and day' (90:5-6; 91:5-6; 92:2).

Psalm 90 reminds us immediately of Psalm 89, concerning the brevity of life (90:3-6; 89:4748): we sense the people still living under the judgement of $\operatorname{God}(90: 7-10 ; 89: 46)$ as the question 'how long?' is repeated in Pss. 90:13 and 89:46). Verses 1-6 lament human mortality; ${ }^{17}$ verses 7-12 reflect on God's wrath. ${ }^{18}$ Verses 13-17 petition God to restore his 'dwelling place' with his people. ${ }^{19}$

\footnotetext{
${ }^{15}$ See Wallace (2007): 88-94.

${ }^{16}$ Targum to Psalm 90 adds 'A prayer of Moses the prophet, when the people of Israel sinned in the desert'.

${ }^{17}$ Verse 2 uses $ד$ יחיל
} 
Christian writers through the ages, including Basil the Great and Athanasius, have commented on the theme of 'refuge in God' in this psalm,.${ }^{20}$ Perhaps the best-known Christian reading of this psalm in English, also focusing on the theme of God as Refuge, is the eighteenth century hymn by Isaac Watts, which is often used at Remembrance Day services in Britain, and also at State Funerals (for example, that of Winston Churchill) to commemorate the permanency of God over and against the futility of war and the fragility of life: ${ }^{21}$

O God, our help in ages past, our hope for years to come, our shelter from the stormy blast, and our eternal home.

A thousand ages, in thy sight, are like an evening gone; short as the watch that ends the night, before the rising sun.

Time, like an ever rolling stream, bears all who breathe away; they fly forgotten, as a dream dies at the opening day. ${ }^{22}$

Psalm 91 is set in the form of a divine oracle and as well as emphasising again that God is our refuge $(91: 2,9)$ it also refers to some specific deliverance from evil. The first promise of God as refuge (vv. 1-8) offers an extraordinary image of God as a mother eagle who protects his people from the 'snare and fowler' and the night-time and noon-day demons. ${ }^{23}$ The second promise of

${ }^{18}$ In v. 10 'seventy years' brings together the theme of human mortality and the years of exile (see for example Jer. 25:11, 12 and 29:10).

19 נח (v. 13) is also found in Deut 32:36.

${ }^{20}$ Athanasius also used this psalm against the Arians in his defence of the 'eternity' of the Son: see Wesselschmidt (2007): 166-9.

${ }^{21}$ Unusually for Watts, no explicit Christian reinterpretation is evident. Vaughan Williams' 'Lord thou has been our refuge' which uses both Watts' lyrics and words form the Book of Common Prayer similarly has no specific Christian emphasis.

${ }^{22}$ See also Robert Burns, 'The First Six Verses of the Ninetieth Psalm' and J.H. Newman, who used this psalm at end of the 'Dream of Gerontius'; in Elgar's version this is sung by the souls in Purgatory ('Lord, Thou hast been our refuge in every generation/ Come back, O Lord! How long: and be entreated for Thy servants / Bring us not, Lord, very low: for Thou hast said, /Come back again, ye sons of Adam') and is followed by the final chorus of Angels 'Praise to the Holiest in the height...'

${ }^{23}$ This image is also found in Exod. 19:4 and Deut. 32:10-12 and here it may allude to the wings of cherubim in temple (1 Kgs 6:23-28) suggesting God's everlasting care for his people despite its destruction. 
refuge (vv. 9-13) refers instead to God sending protective angels. ${ }^{24}$ The third promise (vv. 14-16) consist of eight blessings, using eight verbs of protection: here, unusually in the Psalms, God speaks in the first person taking on a persona more common to the prophetic literature.

The evidence from Qumran suggests that Psalm 91 was used as an apotropaic text on amulets, magical papyri and house walls (vv. 5-6 or 10-13 were usually used). ${ }^{25}$ This might explain the background to the citation of vv. 11-12 by Satan in Jesus Christ's temptations, where Satan uses what would have been well-known texts: 'It is written, "He will give his angels charge of you" and "On their hands they will bear you up, lest you dash your foot against a stone" (Matt. 4:6). Similarly v. 13, which refers to being unhurt by the lion and adder, is used in Lk. 10:19. In Christian tradition Psalm 91 later became known as an 'exorcism text' where Satan is described as a hunter, sin is personified as a wild beast, and Christ has power over both. ${ }^{26}$ This association of Christ's protection over the night-time demons resulted in Psalm 91 being used in Benedictine tradition as the first psalm for Compline Psalms, as the monks and nuns sought protection through the night hours.

Psalm 92, 'A Song for the Sabbath' is linked to 91 by its reference to God as 'Most High' $(92: 1$; see $91: 1,9)$ and to its witness of the downfall of the enemy $(92: 11$; see $91: 8)$. The reference to God being exalted 'on high for ever' in v. 8, at the heart of the psalm, points ahead to the next Kingship Psalm, 93:4. The whole mood of the psalm is of optimistic trust on the part of one who now feels secure in the promises of God. Verses 1-5 are a thanksgiving song; vv. 6-11 are a testimony to God's righteous judgement; and vv. 12-15 testify to God's blessings (using the same metaphor of the 'tree' in the Temple forecourts as is found in Pss. 1:3 and 52:8).

Otherwise the divine order in creation is affirmed, for to remember the Sabbath is to remember that we are all, like Adam and like Moses created in God's image - thus opening the psalm up for Christian as well as Jewish use, with its themes of creation, redemption and God's returning to his people in the future.

Hence in this first part of Book Four these three psalms, each evoking a spirit of prayer and reflection, offer two dominant themes: that of the importance of 'rest', which in Jewish tradition is especially apparent in the association of all three psalms with the Sabbath, and the significance of God as 'refuge', whether facing the fragility of life (Psalm 90), the forces of evil (Psalm 91), or the

\footnotetext{
${ }^{24}$ This may allude to other Mosaic passages such as Exod. 23:20, 23 and 32:34.

${ }^{25}$ Psalm 91 is the 'Fourth Exorcism Psalm' in 4QPs ${ }^{\text {b }}$ and 11Q11 (11QapocrPs).

${ }^{26}$ Wesselschmidt (2007): 173-4.
} 
downfall of the wicked (Psalm 92). The figure of Moses reminds us of a community very different from that created through the royal and nationalistic covenant with David, which was the focus of Book Three: at the very beginning of Book Four we are introduced to a community which is without a king, in which every individual can play their part, both in performing the Sabbath rest and experiencing God as their Refuge.

\section{Part Two: 'The Lord Reigns!'}

\section{Psalms 93-100: The Kingship Psalms}

Psalms 93-100 explicitly and implicitly testify to a greater king than David: God is the supreme King. Moses and Torah still appear in these psalms ${ }^{27}$ but it is the sovereignty of God over the entire cosmos which dominates this collection. Although Psalms 94 and 100 make less explicit references to God's Kingship, the whole collection may be seen as follows:

Psalm 93: God's kingship is for ever

Psalm 94: God will come to judge the nations of the earth

Psalm 95: God's people are called upon to acknowledge God as king

Psalm 96: 'Sing to the Lord a new song'

Psalm 97: God reigns in Zion

Psalm 98: 'Sing to the Lord a new song'

Psalm 99: God reigns in Zion

Psalm 100: The whole earth is called upon to acknowledge God as king

Psalm 93 begins with 'The Lord reigns!' (דיהוד מלד', noting this is a verbal form): verses 1-2 proclaim that God has always been king from time immemorial, and now through the praises of his people he becomes their king. ${ }^{28}$ Verses 3 and 4 take up the myth of God's cosmic battle with the sea, and v. 5 affirms that Jerusalem ('thy house') is where God's eternal rule and earthly abode intersect. ${ }^{29}$ The use of three short lines in verses $1,3,4$ and 5 evokes the rhythm of the rise and fall of the waves of the sea, whilst verse 2 , with its two short lines, evokes, by contrast, the firm establishment of God's heavenly throne.

In Christian tradition Psalm 93 is used at the Feast of Ascension: God's victory over the cosmic and chaotic waters is another means of describing Christ's victory over death, so that the

\footnotetext{
${ }^{27}$ Pss. 93:5 and 94:12 refer to 'decrees' and 'Torah' respectively, and Moses and Aaron appear in 99:7.

${ }^{28} 1 \mathrm{Kgs} 15: 33$ is a good example of the liturgical background for this claim.

${ }^{29}$ There are various similarities here with the ancient Song of the Sea in Exod. 15:1-18, where the battle with the sea refers not to creation but to the escape through the Red Sea; that hymn ends similarly with God celebrating his victory by making his abode in his sanctuary on earth.
} 
phrase 'Christ is risen!' has the same connotations as 'The Lord is king!' - i.e., an event in the past made present in worship and praise. The Gospel reading for Ascension Day, usually from Lk. 24:4453 , thus becomes the lens through which this psalm is read.

Psalm 94 creates a very different tone with its emphasis on 'God of vengeance' (אל-נקמות). Nevertheless, the psalm also picks up the theme in Psalm 92 of God as 'my Rock' (צור (צ') from Ps. 92:15 (Heb v.16); here in 94:22 it is 'the rock of my refuge' (צור מחם") and anticipates the reference to God as Rock in Ps. 95:1. Similarly the reference in Ps. 94:8 to dullards and fools (בערים) and בעם ים is an echo of 92:6 (Heb. v.7) (כםיל בער a). Psalm 94 begins as a lament, pleading with God to inaugurate on earth the rule celebrated in Psalm 93 (vv. 1-2, 3-7); it then turns into a didactic psalm, reminding the congregation of the depth and extent of evil (vv. 8$11,12-15)$. It ends in the confidence that God will come to our aid, and by way of two rhetorical questions (vv. 16 and 20) affirms that justice will prevail.

This is a difficult psalm because of its theme of the 'God of vengeance'. In Christian tradition the reference to the condemnation of the innocent to death ( $v .21)$ has been interpreted as referring to the passion of Christ. ${ }^{30}$ Augustine argued that the psalm is really about the conflict between Divine Grace and Free Will (seen especially in vv. 8-11) where God has to come to our aid. ${ }^{31}$

Psalm 95 begins a sequence of calls on God's people to acknowledge God as king. It is linked to Ps. 94:22 in its image of God as 'Rock' in v. 1, here with all the connotations of the Exodus traditions concerning Meribah and Massa as in Exodus 17. The myth of God's battle with the cosmic sea is again alluded to, but the psalm consists mainly of invitations to praise (vv. 1-6) and an exhortation to obedience by learning from the lessons of history (vv. 7-11).

In Christian tradition the very first call 'O come let us sing to the Lord', and the dual theme of worship and obedient faith with the final promise of 'rest' (v. 11), resulted in this being the key psalm which was recited at the beginning of morning prayer in the Liturgy of Hours. ${ }^{32}$ Still known today as the Venite ('O Come...') it is a key psalm at Morning Prayer. Furthermore, the call to praise

\footnotetext{
${ }^{30}$ See de Solms 2001: 460.

${ }^{31}$ Wesselschmidt (2007): pp. 181-3.

${ }^{32}$ The promise of rest for Christians is debated in Heb. 3:7-11, 15 and 4:3 and 7, which takes up vv. 7-11 of this psalm, and juxtaposes it with the theme of 'rest' in Gen. 2:1-4, arguing that Christians now enter the 'rest' achieved by Christ, which has been there from the beginning and is promised in Psalm 95 .
} 
in v. 5 , 'O come let us worship' inspired the Christmas carol 'Venite Adoremus' ('O Come all ye Faithful') with its theme of giving worship to Christ, the newborn King.

Psalm 96 begins 'O Sing to the Lord a new song'. It also takes up again the combat myth which becomes the 'new song' of deliverance (vv. 1-6), regarding other deities as nothing - a theme most appropriate for the exiles tempted to worship what they could see and touch - Babylonian idols. ${ }^{33}$ From this idea, other nations, now with their deities dramatically 'dethroned', are thus called upon to praise the true Lord (vv. 7-10). Heaven and earth are then called upon to join in this praise to the God who has come and will come again (vv. 11-13).

This psalm is used in 1 Chron. 16:23-33, after Ps. 105:1-15; this shows how in a later period psalms could be re-read as the fulfilment of the promises made to the exiles. This is partly due to the references to the new song (שיר חדש) in verse 1, to the sanctuary (מקדש) in verse 7 and to God's 'courts' (צרות) in verse 8: in the context of the restored Temple, these allusions were interpreted as prophecies about God's coming to his people and hence judging the earth (verse 13) which were now in the process of being fulfilled by God's return to Zion. Its use in the Sabbath liturgy fulfils a similar purpose.

Christians have re-read this again in the light of another fulfilment: God's Kingdom is always entering history, and the 'new song' now is the Kingdom of God inaugurated through Jesus Christ (Mk. 1:14-15). Psalm 96 is often used along with Psalm 97 and 98 in the liturgy for Christmas Day, sometimes with the Old Testament reading from Isa. 9:6-7 (about a royal figure who will bring in the righteous rule of God) along with Lk. 2:1-14 (on the birth of Jesus).

Verse 10 is perhaps the most controversial verse in this psalm. In at least one manuscript, a Christian mistranslation of the Greek into Latin adds 'The Lord reigns from the tree' (Dominus regnavit $a$ ligno'): Christian illuminated manuscripts in the Middle Ages have interpreted this psalm with images of Christ on the cross. ${ }^{34}$

\footnotetext{
${ }^{33}$ We saw earlier how this theme of the new song and the nothingness of other gods was also used in the exilic prophetic book Isa. 42:10-12 and 43:16-21.

${ }^{34}$ Wesselschmidt (2007): 195
} 
Psalm 97 returns to a theme which ended Psalm 93: God's rule in Zion. Here the combat myth takes up the imagery of God as Lord of the storm gaining victory over other deities (vv. 1-7) which culminates in Zion and Judah rejoicing at his exaltation (vv. 8-12). ${ }^{35}$

Christians have interpreted the idea of God gaining victory over the gods and dwelling among his people to refer to the incarnation, where Christ personifies Zion; so this psalm, along with Psalms 96 and 98, also became an important part of the liturgy for Christmas Day. It is also used at Epiphany, which celebrates the coming of the wise men to worship the baby Jesus as Christ the King.

Psalm 98 is paired with 96 in its call to 'sing a new song' (vv. 1-3) and, using imagery from a combat myth, calls on all the earth to worship the Lord as King (vv. 4-6); even the sea and floods, symbols of chaos, join in this celebration (vv. 7-9).

The Christian Fathers read the references to the 'new song' in both Psalms 96 and 98 as 'the church's song to Jesus Christ': the universal application of the psalm made such an appropriation possible, for this is a song for Gentiles as well as Jews ${ }^{36}$. With Psalms 96 and 97 it is part of Christmas liturgy, and here the Gospel reading is usually from Jn. 1:1-14. Verses 4-9 were the inspiration for Isaac Watts' Christmas hymn, 'Joy to the World'. Heinrich Schütz's 'Singet dem Herr ein neues Lied' was based on Psalm 98, as was James MacMillan's 'A New Song', recorded only in 2006.

Psalm 99 is paired with 97, and again uses the myth of the victory of the storm god to celebrate God's universal world rule, which is particularised in his dwelling in Zion (vv. 1-5). Moses the intercessor (as in Psalm 90) is recalled, along with Aaron and Samuel (vv. 6-8), to illustrate again that God's Kingship pre-dates that of David. The psalm ends with a call to worship God in Zion (v. 9).

Again the 'indwelling' theme is taken up by Christians who see this is fulfilled in the birth of Jesus. Giovanni Gabrieli's Motet for Six Voices, 'Timor et Tremor', is based upon this psalm.

Psalm 100 is more of a thanksgiving than a hymn, and is paired with 96 in its call to worship God in Zion. Here the call is to all nations as well as Israel, using a common exilic theme of the people as God's flock and God as their Shepherd (vv. 1-3). ${ }^{37}$ The psalm ends with a call to process together to the Temple (vv. 4-5).

\footnotetext{
${ }^{35}$ We may note how similar this is to the way the Babylonian god Marduk, after his victory over Tiamat, builds a sanctuary to dwell in; so too the Canaanite deity, Baal, celebrates his victory over Mot by building a palace.

${ }^{36}$ See Wesselschmidt (2007): 199 (Eusebius); also de Solms 2001: 473 (Athanasius and Augustine).

${ }^{37}$ See for example exilic texts such as Pss. 74:1; 79:13; Jer. 23:1 and Ezek. 34:31.
} 
This perspective of God's 'steadfast love' being poured out over all the earth has made this a popular psalm for Christians. It was the inspiration for the sixteenth century 'All People that on Earth do Dwell', attributed to Louis Bourgeois of John Calvin's church in Geneva, translated from the French by William Kethe. A very different version from the same period is Christopher Tye's 'Omnes Gentes'. A century later Thomas Ken composed a doxology from this psalm which became known as the 'Old Hundreth':

Praise God, from Whom all blessings flow

Praise Him, all creatures here below;

Praise Him above, ye heavenly host;

Praise Father, Son and Holy Ghost.

In Psalms 90-92, the theme of God as Refuge was expressed through reflective prayer and quiet instruction; in the second part of Book Four, the theme of God as King in Psalms 93, 95-100 is expressed as the 'new song', quite literally, in exuberant praise. Significantly, nowhere in either collection do we find any reference to David. There are, however, several telling references to God's choice of Zion, to which, after a victory over other nations and their deities, he will return. The most obvious examples include Pss. 93:5 ('holiness befits your house, O Lord, forevermore'); 96:6 ('strength and beauty are in his sanctuary'); 96:8 ('bring an offering, and come into his courts'); 97:8 ('Zion hears and is glad'); and 99:2 (The Lord is great in Zion). ${ }^{38}$ It is not difficult to see why this specific collection would have been so important for the post-exilic community to preserve upon their return to Zion, for they were indeed without a Davidic king. But Zion had in part been restored to them; and here, too, was reminder that God always has been and always would be their King.

\section{Part Three: Reconsidering David}

\section{Psalms 101-103: A Brief Davidic Collection}

David returns briefly at this point, for Psalms 101 and 103 each have Davidic headings; the overall theme is one of obedient faith in suffering and God's compassion within it; Psalm 102, without a Davidic heading in the Hebrew, also fits this theme. Here however we might also perceive a more idealised view of David as a coming figure and a greater emphasis on the community of faith who, in the present moment without a king, embody these aspirations of 'royal rule'.

38 The theme was also alluded to in Psalm 91:2 and 92:1; it also comes in 101:8 and 102:16 and at the very end of Book Four, in 106:47. See Gillingham (2005):308-41. 
Psalm 101 speaks of a Davidic figure who seeks to be a model servant of his people. The fact that Zion is referred to (v. 2, also found in the following psalm [102:21] and in the last psalm of the previous collection [100:4]), suggest this is an idealised Davidic king who first prays for divine favour (vv. 1-2) and then makes seven promises of fidelity (v. 3-8). The emphasis on obedience (admittedly without any specific reference to the Torah) reminds one of the Deuteronomic (and hence Mosaic)

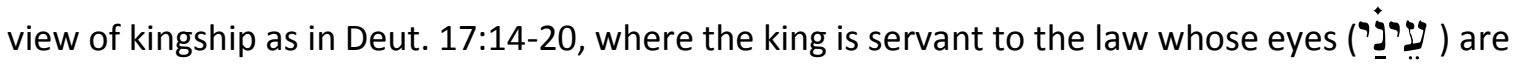
focussed on what is true and right (verses $3,5,6,7)$.

A similar royal 'manifesto' of obedient service is also found in, for example, Lk. 4:16-21, where Jesus applies a similar passage concerning an obedient servant from Isa. 61:1-2.

Psalm 102 has no Davidic heading; it is an anonymous individual lament, whose first part is a plea for God to hear (vv. 1-11), followed by a statement of confidence in the eternal God who once ruled from Zion as king and who will build up this city once again (vv. 12-22). The final part is a prayer for the psalmist's life to be spared (vv. 23-28). There are some correspondences with Psalms 90-92, for example the sense of the permanence of God contrasted with the fragility of human life (Ps. 102:13), a theme which was expressed similarly in Pss. 90:2 and 92:7.

One of the issues of interpretation in this psalm is whether the 'affliction' is, literally, about an individual (the title in the LXX gives this a Davidic orientation, for example) or a dramatic personification of Zion and/or the Jewish community itself, with some affinities with the book of Lamentations.

Cyril of Jerusalem wrote about how this world will perish (vv. 18-28) but urges that humans can receive the gift of immortality through Christ. ${ }^{39}$ However, the psalm has usually been read by Christians not so much doctrinally as personally: it has been marked out, at least from Augustine onwards, as one of the seven penitential psalms of the church. ${ }^{40}$ In the Christian liturgical year it is often read on New Year's Day, in part because of its theme of the brevity of human life and the dependence of all humanity upon God.

Psalm 103, with its Davidic heading, continues the theme of divine permanence over human transience, but focuses on God's justice and compassion rather than on his judgement and anger. Verses 1-5 speak of God's forgiveness, reminding us of the image of the eagle in Ps. 91:1-6; vv. 6-14

\footnotetext{
${ }^{39}$ See Wesselschmidt (2007): 209-10. This is in part influenced by the way that Heb. 1:10-12 reinterprets Ps. $102: 25-26$ as the address of Christ stating his superiority over the angels.

${ }^{40}$ The seven penitential psalms are $6 ; 32 ; 38 ; 51 ; 102 ; 130$ and 143.
} 
are about God as healer of the nation, citing an early creed in Exod. 34:6-7 about God's mercy being greater than his anger. Verses 15-18 focus again on human transience, whilst vv. 19-22 emphasise divine permanence, reflecting again on the creed in Exodus 34. For those in exile, this psalm, with the authority of David in its heading and the authority of Moses in its Exodus creed, this would have been an important inspiration for faith and obedience..

In Christian tradition Ambrose took the imagery of the eagle and renewal of our youth (v. 5) as a reference to new birth after baptism. ${ }^{41}$ The psalm has inspired several notable hymn-writers because of its themes of the mercy of God alongside his creative power. Henry Francis Lyte wrote:

Praise, my soul, the King of Heaven

To his feet thy tribute bring;

Ransomed, healed, restored, forgiven

Who like me his praise should sing?

Joachim Neander's German chorale, Lobe den Herren was translated into English as 'Praise to the Lord! The Almighty, the King of Creation'; a much more recent version is 'Bless the Lord O my Soul', from Godspell.

This small collection reflects nostalgically on David, the one who suffers on behalf of his people yet remains obedient to his faith in God, reverting to some of the themes in Book Two of the Psalter. Yet here the figure of David either refers to a new coming king (Psalm 101) or is more representative of the people as a whole (Psalms 102 and 103) so that the ' $I$ ' of David becomes the 'we' of the people. ${ }^{42}$ The reception history of these psalms, which also applies them to the community of faith, takes up a key motif in this collection: that the mercy of God is greater than his judgement.

We return now to the other corporate themes in the last three psalms of Book Four - but the fact that the first and last verses of Psalm 103 ('Bless the Lord, O my Soul') are identical to the first and last verses of Psalm 104 show how important it is to see the connection between the personal and communal, as well as between the covenants with David and with Moses.

\section{Part Four: The Great Themes of Creation and Exodus}

\section{Psalms 104-106: Reconsidering Moses}

\footnotetext{
${ }^{41}$ This is influenced by the tradition that the eagle could renew its plumage (and hence its youth) by flying near the sun and then plunging into the water.

${ }^{42}$ This is another theme in exilic literature: see, for example, the 'democratisation' of the figure of David in Is.55:3.
} 
Psalm 104 returns to the theme of God as Creator, and brings into the Psalter, for the first time, the expression 'Hallelujah!' which is continued over the next two psalms as well. Psalms 105106 turn to God as the one who works through history, going further back to Abraham and then to the time in Egypt. Psalm 105 celebrates what God has done and Psalm 106 highlights what the people have not done, and Book Four ends with a prayer that God might gather his people from the nations (106:47).

Psalm 104 is closely linked to Psalm 103 not only in the call to 'Bless the Lord, O my Soul' but also in the reference to 'his messengers' (מל אכביר) in v. 4 (see Ps. 103:20), as well as the use of verbs such as 'renew' (דשדש) in v. 30 (see Ps. 103:5) and the imagery of 'dust' (עפכר) in v. 29 (see Ps. 103.14). What is different, however, is that the image of God as the compassionate and healing parent in Psalm 103 has now been transformed into a hymn to God as the powerful cloud-rider and sustainer of all. Verses 1-18 develop the theme of God as the storm deity who defeats the forces of chaos, and who, like the Canaanite Baal at Ugarit, rides the clouds in a chariot (vv. 1-9) yet provides fertility for the whole world through the waters beneath the earth (vv. 10-12) and through the rains from the heavens above (vv. 13-18). Verses 19-30 develop the theme of God as bringer of light and life into the world, using the imagery from the fourteenth century Egyptian hymn to Aten. ${ }^{43}$ The psalm ends with a prayer for justice on earth (vv. 31-35).

Just as the Jewish poets adapted this hymn of creation from Canaanite and Egyptian ideas about God as Creator, so Christian writers have adapted the theme in this psalm in their own way. The references to the Spirit renewing Creation (vv. 24-30) have been read as references to the Spirit restoring the human race within the Church. ${ }^{44}$ The early Church Fathers saw the expression of the Trinity here, in God the Creator, God the Word, and God the Spirit. ${ }^{45}$ The references to the earth bringing forth wine, bread and oil in v. 15 allowed the Fathers to speak of ordinary things being given sacramental significance. Perhaps the best-known Christian adaptation of this psalm is the thirteenth-century 'Canticle to the Sun' by Francis of Assisi. In the nineteenth century Robert Grant wrote this version:

\footnotetext{
${ }^{43}$ Aten imagery may be seen in 'when you dawn they live' and 'when you set they die' (vv. 22, 27-30). See Day (2013): 211-28. See also Dion (1991): 43-71.

${ }^{44}$ Lectionary readings often use this as a Pentecost Psalm with the Gospel readings as John 20:19-23, Acts 2:121.

${ }^{45}$ Wesselschmidt (2007): 235-6.
} 
O Worship the King all glorious above;

O gratefully sing his power and his love;

Our shield and defender, the Ancient of Days

pavilioned in splendour and girded with praise...

In Psalm 105 we move from the universal focus on creation to the particular focus on Israel's history. Psalm 104:33 avows 'I will sing to the Lord'; Ps. 105:2-3 begins 'sing to him, sing praises to him!'. Here history starts not with Moses but with Abraham (vv. 1-6; also referred to again vv. 9 and 22); this moves on to retell the story of God's covenant with Israel's ancestors, starting with Abraham (vv. 7-11), followed by an account of the entry into Canaan (vv. 10-15). The emphasis on adversity and triumph allows for the development of the theme, 'a foreign land': so the earlier story of Joseph in Egypt (vv. 16-22) is followed by that of Israel in Egypt (vv. 23-38) and then Israel in the desert (vv. 39-45, ignoring the rebellion tradition which is so clear in Psalm 106). ${ }^{46}$ The overall focus is not only on the gift of the land but also on the giving nature of God, who can always do new things.

The re-use of this psalm in 1 Chron. 16:8-22 testifies to the ways in which 'God's renewal through history' was understood upon the actual return to the land, again showing the interpretation of some of the psalms in later biblical tradition. Its partial use by the priest Zechariah in Lk. 1:72-73 points to another re-use, in a Christian context, this time viewed through the coming of Jesus Christ. Psalm 105 is also used at Pentecost to refer to the history and journey of all God's people, scattered abroad but now bound together in their covenant faith.

Psalm 106 is, by contrast, a lament. Instead of the grace of God pervading the psalm, we now encounter a sense of God's anger (although vv. 4-5 and 47 do show some hope for God's compassion). Some themes are shared with Psalm 105, showing these psalms are to be read as a pair: just as Ps. 105:45 closes with 'Hallelujah', Ps. 106:1 opens with the same call to praise. God 'remembers' (using (זכר) his people in Ps 105:42 and the people are to 'remember' (זכר) God in Ps. 106:4. Ham (the 'hater of Israel') is found in both Pss. 105:23, 25, 27 and 106:22, in the former as a sign of God's protection and in the latter as a sign of God's judgement. Moses is more central in Psalm 106: in Ps. 105:26 it is 'Aaron' who is chosen, whilst in Ps. 106:23 it is Moses, who also appears in vv. 16 and 32. The last psalm of Book Four has some correspondences with the first: for example, as in Psalm 90, Exodus 32 is also used here (Ps. 106:23), followed by the same call to repentance and the same appeal to God's steadfast love (Pss. 90:14 and 106:45) .

\footnotetext{
${ }^{46}$ The paired psalms which celebrate the Exodus theme do so positively on the one hand (Psalms 77; 80; 105) and negatively on the other (Psalms 78; 81 and 106).
} 
After a prayer for God's favour to return (vv. 1-6) the focus is on Israel's rejection of God: the rebellion at the Red Sea (vv. 7-12), the testing of God in the desert (vv. 13-15), the uprising against Moses and Aaron (vv. 16-18), the Golden Calf (vv. 19-23), Baal of Peor (vv. 24-31), the waters of Meribah (vv. 32-33) and even child sacrifice (vv. 34-46). The psalm ends with a plea for God to gather his people from the nations (v. 47), reminding us of the plea to restore the monarchy in Ps. 89:49-51. The final doxology is as unexpected in this psalm as is the doxology at the end of Psalm 89: its purpose is to show another Book of Psalms is complete. ${ }^{47}$ Leaving this doxology aside, then, we can see that just as Book Four started with Moses, the mercy of God, and a call to repentance, it now ends in the same way.

Taking Psalms 104-106 as a whole, it is intriguing to see that the final two psalms of this collection illustrate so well the importance of story through poetry, and indeed bring together both the positive and negative themes of the entire book concerning God: Psalm 105 testifies to God as the refuge of his people, as the sovereign king, and as one whose mercy outweighs his judgement, whilst Psalm 106 testifies to the fragility of God's people, to their lack of trust in his Kingship, and to their disobedience rather than obedient faith.

And so throughout all four collections within Book Four we learn not only about the way God deals with his people in times of change but also about different facets of the character of God. In the first collection God is seen to be the people's Refuge amidst the vicissitudes of life. In the second collection God is proclaimed as the people's King, when the covenant with the human king had come to an end. In the third collection God is viewed as the Merciful Ruler who governs his people in justice and righteousness. And the fourth collection teaches that God is both Creator and Redeemer, the one who still has a plan for his people despite their dislocated history.

The covenant faiths of Judaism and Christianity have emerged from the same roots, and each tradition has had its fair share of experience of failure which has been overcome by the persistence of divine grace. Although Book Four is only a small part of the overall story expressed through the poetry of the entire Psalter, it undoubtedly bears witness to this. As part of the entire story of the Psalter, this collection of seventeen psalms can be read and understood as a whole to inspire Jews and Christians alike - firstly, to encourage us to repentance, and second, to urge us to hope for the renewal and restoration of our faith in a manifestation which is both physical and spiritual.

\footnotetext{
${ }^{47}$ Interestingly although the psalm is used, along with Psalm 105, in 1 Chron. 16:35-36, only the doxology is used: nothing is made of the accounts of Israel's rebellion under Moses.
} 


\section{Bibliography}

Brueggemann, W. and W.H. Bellinger, Jr.

2013 Psalms (New Cambridge Bible Commentary; New York/Cambridge: Cambridge University Press).

Ceresko, A.R.

1990 'The Sage in the Psalms' in J.G. Cammie and L.G. Perdue (eds.), The Sage in Israel and the Ancient Near East (Winona Lake: Eisenbrauns):217-31.

Clifford, R.J.

2003 Psalms 73-150 (Nashville, TN: Abingdon Press).

Creach, J.

1998 'The Shape of Book Four of the Psalter and the Shape of Second Isaiah', JSOT 80: 63-76.

Day, J.

2013 'Ps. 104 and Akhenaten's Hymn to the Sun' in Gillingham 2013: 211-28.

de Solms, E. (trans. and commentary)

2001 Bible chrétienne V: Livre des Psaumes (Éditions Anne Sigier: Québec) 2001.

deClaissé- Walford, N. L.

1997 Reading from the Beginning: The Shaping of the Hebrew Psalter (Macon, GA: Mercer University Press).

Dion, P. E.

1991 'YHWH as Storm-god and Sun-god. The Double Legacy of Egypt and Canaan as Reflected in Psalm 104', ZAW 103: 43-71. 
Gillingham, S.

2005

'The Zion Tradition and the Editing of the Hebrew Psalter' in John Day (ed.), Temple and Worship. Proceedings of the Oxford Old Testament Seminar (Sheffield: Sheffield Academic Press): 308-341.

Gillingham, S. (ed.)

2013 Jewish and Christian Approaches to the Psalms: Conflict and Convergence (Oxford: Oxford University Press).

Goulder, M.D.

1975 'The Fourth Book of the Psalter', JTS 26: 269-89.

Hossfeld, F.-L. and T.M. Steiner

2013 'Problems and Prospects in Psalter Studies', in Gillingham 2013: 240-58.

Hossfeld, H.-L. and E. Zenger

2000 Psalmen 51-100, 2 Teilband, (Freiburg: Herder). ET Psalms 2: A Commentary on Psalms 51-100 (trans. L.M. Maloney; Minneapolis, MN: Fortress Press, 2005).

2008 Psalmen 101-150, 3 Teilband (Freiburg: Herder). ET Psalms 3: A Commentary on Psalms 101-150, (trans. L.M. Maloney; Minneapolis, MN: Fortress Press, 2011).

Howard, D. M.

1993 'A Contextual Reading of Psalms 90-94' in J. Clinton McCann (ed.), The Shape and Shaping of the Psalter (JSOTSup, 159; Sheffield: JSOT Press): 108-23.

1997 The Structure of Psalms 93-100: Their Place in Israelite History (Winona Lake, IN: Eisenbrauns).

Kim, J.

2008 'The Strategic Arrangement of Royal Psalms in Books IV-V', WTJ 70: 143-58.

Neale, J.M. and R.F. Littledale (eds.) 
1874 A Commentary on the Psalms from Primitive and Mediaeval Writers, Volume III: Psalm LXXXI to Psalm CXVIII (London: Joseph Masters \& Co).

Terrien, S.,

2003 The Psalms: Strophic Structure and Theological Commentary (Grand Rapids, MI/Cambridge: W.B. Eerdmans).

Van Harn, R.E. and B.A. Strawn (eds.)

2009 Psalms for Preaching and Worship: A Lectionary Commentary (Grand Rapids, MI/Cambridge: W.B. Eerdmans).

Wallace, R.A.

2007 The Narrative Effect of Book IV of the Hebrew Psalter (Studies in Biblical Literature, 122; New York: Peter Lang).

Wesselschmidt, Q.F. (ed.)

2007 Psalms 51-150 (Ancient Commentary on Scripture Old Testament, 8; Downers Grove, IL: Inter-Varsity Press).

Wilson, G.H.

1985 The Editing of the Hebrew Psalter (SBL Dissertation Series, 76; Chico, CA: Scholars Press.

Zenger, E.

1991 'Israel und Kirche im gemeinsamen Gottesbund. Beobachtungen zum theologischen Programm des 4. Psalmenbuchs', in M. Marcus, E.W. Stegemann and E. Zenger (eds.), Israel und Kirche heute. Beiträge zum christlich-jüdischen Dialog. FS E.L. Ehrlich (Freiburg/Basel/Wien: Herder): 238-57. 